\title{
ASSAY OF ENGLISH CUISINE: ADVENT AND ADVANCEMENT
}

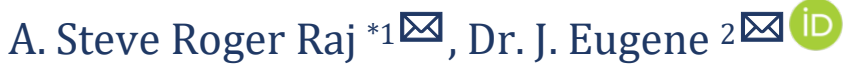 \\ ${ }^{* 1}$ III Year B. Sc in Hospitality \& Hotel Administration, Institute of Hotel Management Catering \\ Technology and Applied Nutrition, Chennai - 600113, India \\ ${ }^{2}$ Lecturer, Institute of Hotel Management Catering Technology\& Applied Nutrition, Chennai - \\ 600113, India
}

DOI: https://doi.org/10.29121/granthaalayah.v8.i9.2020.1347

Article Type: Research Article

Article Citation: A. Steve Roger Raj, and Dr. J. Eugene. (2020). ASSAY OF ENGLISH CUISINE: ADVENT AND ADVANCEMENT. International Journal of Research GRANTHAALAYAH, 8(9), 63-70. https://doi.org/10.29121/granthaa layah.v8.i9.2020.1347

Received Date: 30 August 2020

Accepted Date: 25 September 2020

Keywords:

Cuisine

English

Evolution

Tradition

Desserts

History

\section{ABSTRACT}

England is a country that has experienced various changes throughout the course of its history. From its land being invaded to colonizing in other lands, the cuisine has been under the constant state of adaptation and improvisation in order to meet the dietary needs of the people. This research is done to give an insight into the English Cuisine with respect to history in order to better elucidate the nature of the English food in adaptive flux through the centuries. This study shows historical data excavated from evidential books published throughout those centuries as well as articles and data published on the subject. The objectives of the research done are:

- To understand the nature of the English cuisine.

- To understand the history and origin of the English food developed.

- To understand the influences the cuisine had on other countries.

- To analyze the past events and the changes made that affect the current English Cuisine and evolution undergone.

- To better understand the future of the cuisine in terms of survival.

\section{INTRODUCTION}

A part of the United Kingdom, England is a country that shares immediate borders with Scotland to its north and Wales to its west. England occupies more than half of the island of Great Britain. With a fertile land, England has supported a thriving agricultural economy for thousands of years. When comparing to other parts of the United Kingdom, the physical environment and natural resources of England are more favourable to agricultural. In the early $19^{\text {th }}$ century, England became the world's most industrialized country as it was at the epicenter during the worldwide Industrial Revolution. The land was first invaded by Romans in 55 or 54 AD. Then it saw a major change with the settlement of Germanic people between $5^{\text {th }}$ to $7^{\text {th }}$ centuries introducing the Romano-British to Anglo-Saxon culture. $^{1}$

English food at these times had slowly being influenced by the invaders and settlers from being simplistic and insipid to procuring and cultivating crops and adapting techniques in cooking to improvise the food served.

\footnotetext{
${ }^{1}$ Smith, L., \& Kishlansky, M. (2020, July 26). Ancient Britain. Retrieved from: https://www.britannica.com/place/United-Kingdom/Ancient-Britain

(c) 2020 The Author(s). This is an open access article distributed under the terms of the Creative Commons Attribution License, which permits unrestricted use, distribution, and reproduction in any medium, provided the original author and source are credited. 


\subsection{AGRICULTURE AND LIVESTOCK}

Four major cereal crops were grown by English farmers 500 years ago. They are rye, wheat, oats and barley. Along with this, pulse crops of beans and peas were also grown. They also kept sheep, pigs, poultry and cattle. Potatoes, sugar beet, turnips, rapeseed amongst others have been added to the sixteenth-century list of crops during the course of the last five centuries. Only sugar beet, out of the all those, were introduced three centuries before 1850. Although these crops and livestock are kept by English farmers of today, dramatic change seen in the cereal crops can be credited to the plant breeding that took place during the twentieth century. On such similar terms, selective breeding can be credited with the transformation of livestock characteristics.

Fig.1 takes a measure of soil quality of England in 1930s, taking account of a wide variety of soil attributes influencing productivity, including depth, water conditions and texture; and also the characteristics of the site, including aspect. $^{2}$

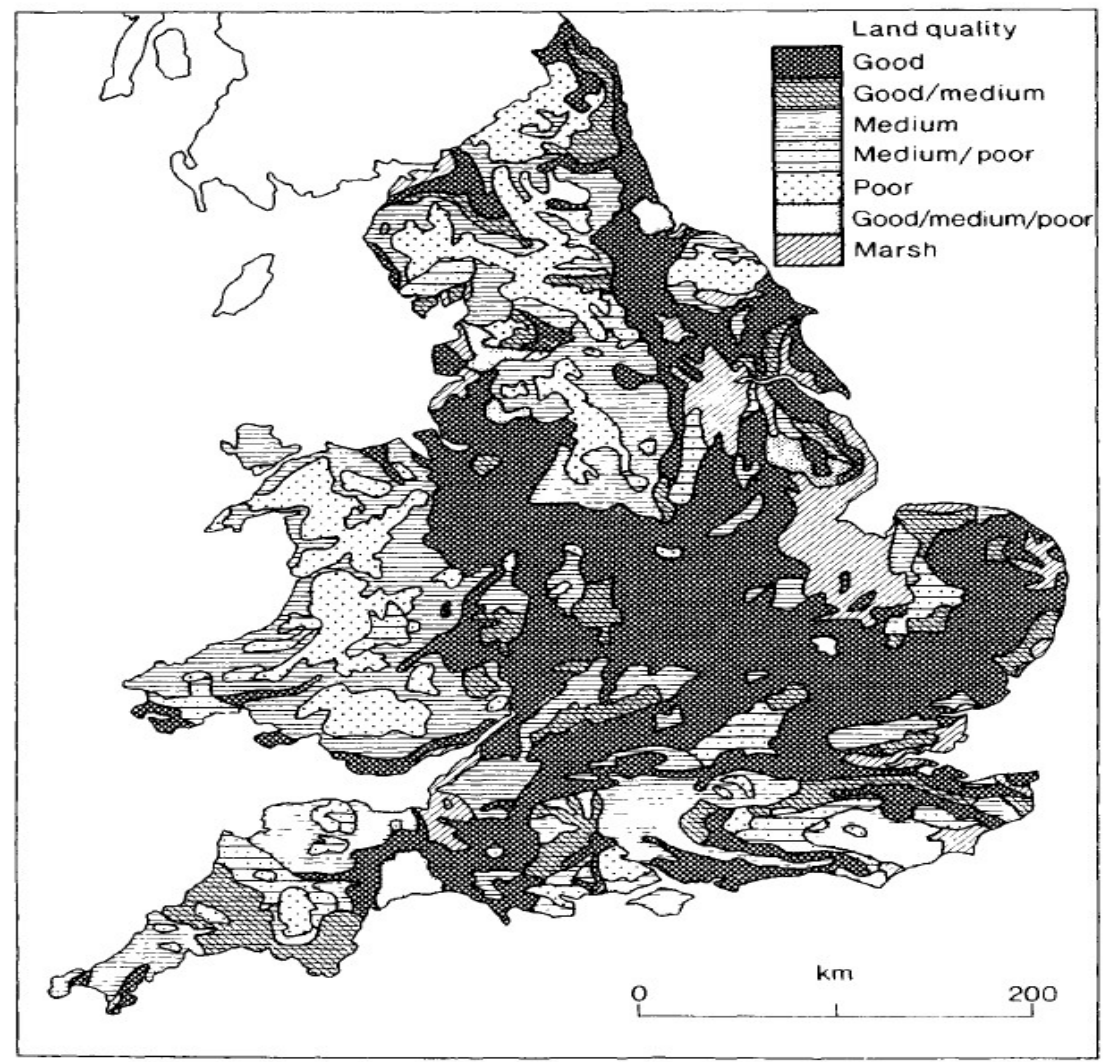

Figure 1: Land Quality in the 1930s.

Source: Mark Overton (1996). Agricultural Revolution in England.

\subsection{SEAFOOD}

There was a skilled and organised commercial fish-keeping industry for four hundred years in England. It was mainly of carp for the London market. Many kinds of freshwater fish were likely in demand by the wealthy, who sought the status eating such fishes that were conferred. In the Londoners were consuming fish on such a high scale in the $17^{\text {th }}$ century that there were concerns that stocks would be over-fished. Mrs Beaton was writing, in her book from 1860's 'The Book of Household Management' that fishes such as carp, pike and trout were rarely bought. The UK market for freshwater fish had reduced drastically by the end of the 19th century. The prospering marine fishing fleets and the rapidly developing rail network made it possible for retail fishmongers to deliver marine fish throughout the country. Ponds and especially the carp living there were gone in the 1950's. Soon trout farming for 
the table would revive the UK freshwater industry only to be quickly plateaued however. It is also seen there has been limited growth in other species as well in England, Wales and Northern Ireland. But Scotland saw a growth in salmon farming. The very rapid growth of aquaculture took place throughout the world, including the England. Oysters were considered very numerous in the 19 th century to an extent where it was to be food for the poor. ${ }^{3}$

\section{TRADITIONAL DISHES AND FOREIGN INFLUENCES}

\subsection{INTRODUCTION}

History of the English Empire requires relating it with other European countries, and the importing of ideas and most importantly ingredients from countries such as North America, China and India. This includes the time of the British Empire as well as the result of it, post-war immigration. As a result of that, traditional foods such as roasted and stewed meats, game and meat pies, saltwater and freshwater fish and even cheese and bread have ancient origins.

England has become renowned for its dairy products. One particular rich clotted dairy product produced from the southwest side of England is the Devon cream. England is also known for its world-class cheese produced in its numerous counties, each of fine variety and being named from its place of origin, similar to wines from France and their region. Pubs in the country are popular for lunch. Many still enjoy a typical "ploughman's lunch," which consists of cheese, pickle, bread and sometimes cold meat, with a generous glass of ale. English cuisine was also famous for its pies. One of the earliest mentions of the word pie was in a medieval scroll consisting of around 200 recipes called 'The Forme of Cury', where it was referred to as 'Pye' in the recipe 'Pumpkin Pye'. 4

\subsection{TRADITIONAL DISHES}

\section{Sunday Roast}

The Sunday roast is a very common traditional meal of English cuisine. The Sunday roast is said to have come to prominence in the 1480's during the reign of King Henry VII. The British used to consume a considerable amount of meat. The Yeomen of the Guard, who were the royal bodyguards, have affectionately been given the name as "Beefeaters" since the 15th century due to their fondness for consuming a lot of roast beef. The Sunday dinner traditionally comprises of a roasted joint of meat, beef or lamb, accompanied by roasted potatoes and assorted vegetables. Vegetables themselves generally roasted or boiled, served with gravy. Yorkshire pudding and gravy was originally served as filler but now is served often as an accompaniment to the main course. ${ }^{5}$

\section{Fish and Chips}

In 1839, Charles Dickens in one of his most famous novels, Oliver Twist, referred to a "fried fish warehouse". The first ever fish and chip shop in the North of England is dated around 1863 opened in the town of Mossely, near Oldham, Lancashire. A man named Mr. Lees sold fish and chips first from a wooden hut in the market and then later moved the business to a permanent shop across the road. The inscription in the window read, "This is the first fish and chip shop in the world". 6

\section{Sandwiches}

England may rightly claim to have coined the word "sandwich", although the $4^{\text {th }}$ Earl of Sandwich, John Montagu, was not the first person to incorporate a filling to bread. But as the claims go, this creation came into existence through extensive nights spent at the gaming table. The Earl was an avid gambler would refuse to leave the table to have his meals. Therefore, he would request for slices of meat between two slices of bread. As he would have some

\footnotetext{
${ }^{3}$ Hambrey, J. and Evans, S. (2016). Aquaculture in England, Wales and Northern Ireland: An Analysis of the Economic Contribution and Value of the Major Sub-Sectors and the Most Important Farmed Species. Hambrey Consulting, ISBN No: 978-1-911073-00-0

4Pegge, S. (1780). The forme of cury: A roll of ancient English cookery. London: Printed by J. Nichols.

5Lemm, Elaine (2019, June 12). A Brief History of the Great British Sunday Roast. Retrieved from https://www.thespruceeats.com/historyof-the-british-sunday-roast-4149600

${ }^{6}$ Castelow, Ellen. The History of Fish and Chips. Retrieved fromhttps://www.historic-uk.com/CultureUK/Fish-Chips/ International Journal of Research -GRANTHAALAYAH 
company while playing, it is said that they started evoking his name in association to the peculiar eating habit they witnessed and hence the name. ${ }^{7}$

\section{Tea}

Afternoon tea in England was first introduced in the year 1840 by Anna, the seventh Duchess of Bedford. As there was a long gap between lunch and dinner at the time, this was introduced to act as timely filler. The Duchess seemed to be hungry in that gap around four o'clock in the afternoon. The Duchess would ask for a tray of bread and butter, cake and most importantly tea be brought to her room during that late afternoon.

Repetition of the same food took place, every afternoon, but she soon began inviting her friends to join the new 'tea break'. Therefore, news of such pause between the two meals was popularized with the world.

It is said that society and upper-class women would be dressed accordingly for their afternoon tea. Tea then usually came to be served in the drawing room but occasionally outdoors as well. A traditional afternoon tea comprises of a selection between different kinds of sandwiches, scones along with clotted cream and fruit preserves. A variety of cakes and pastries are also served. Tea grown in India or Ceylon is poured from silver tea pots into delicate bone china cups. ${ }^{8}$

\subsection{ENGLISH BREAKFAST}

English breakfast became more known throughout the nation around the $13^{\text {th }}$ century through an English institution consisting of a group of upper-class traditionalists known as the 'Gentry'. The Gentry were known for their hospitality and generous, hearty breakfasts they would gladly provide in their country houses for passing travelers and visitors. This became an ample opportunity for the gentry to display the 'wealth' of their estates with the breakfast table. The quality of the meats, vegetables and ingredients produced on their lands are well showcased with this act of hospitality. It was also to show off how the cooks were able to skillfully prepare a selection of typical Anglo-Saxon (a descent they prided with) breakfast dishes not only for the residents but also the guests of the house providing variety to choose from and feast upon. With the Victorian era came more merchants and industrialists in the wealth class, who followed with the tradition of the declining gentry's way of breakfast, therefore popularizing it well and through. There may have been a few additions but English breakfast has remained almost the same with serving the typical dishes throughout all these centuries. The full English breakfast is also known as cooked breakfast or fried breakfast. It normally consists of a combination of bacon, fried bread, grilled tomatoes, baked beans, black pudding, sausages, fried mushrooms, and eggs, which may be fried, scrambled or boiled. Hash browns can be added if adhering to tradition. ${ }^{9}$

\subsection{FOREIGN INFLUENCES}

The land of Britain was first invaded by the Danish and Norwegian Vikings around the 9th century. These invaders introduced the techniques of smoking and drying fish to the British people. Knights returning from Middle East brought spices from their crusades. The Normans later arrived, imparting French influence to the cuisine along with also encouraging the use of rabbit as meat.

\section{Indian Influence}

The expanding trade routes established by the British Empire further helped their interests in introducing various new flavors, tastes and dishes into their classical set cuisine. Though their traditional food was embedded in rich history, having a stable cuisine carried on for centuries without change, their successful colonization was the reason for allowing the modern face of the cuisine to thrive in the dynamic diversity. And its biggest influence on colonization came with India. With spices like cumin, cinnamon, pepper, turmeric, and coriander, the cuisine flourished providing further enrichment to its kitchens. Over the 19th century, due to the support of Queen Victoria the Indian cuisine came into limelight for the Brits.

7Wilson, B., 2010. Sandwich. London: Reaktion Books.

8Ukessays.com. 2016. Traditional English Food And The History History Essay. Retrieved from:

https://www.ukessays.com/essays/history/traditional-english-food-and-the-history-history-essay.php

${ }^{9}$ Bule, G., 2020. History Of The Traditional English Breakfast. Retrieved from: https://englishbreakfastsociety.com/full-english-breakfast.html International Journal of Research -GRANTHAALAYAH 
Among those, the famed Chicken Tikka Masala was introduced to Britain. It is claimed to have originated from the Punjab region of India. Mulligatawny soup was another dish of Indian influence popular among the Brits. During the British Raj, it came into creation for people who wished for soup from a cuisine which had none. Therefore, a soup made from curry, turmeric and pepper as base was served. ${ }^{10}$

\section{Roman and Italian Influence}

Roman roots came to Britain in 43 AD when Emperor Claudius and his troops first landed on the South Coast of Britain. The inhabitants of Britain enjoyed Roman imports such as wine, olive oil, fruits, vegetables and dishes during this time. But the same influence that seem to flourish in Italy didn't prove to last long with Britain due to its Nordic climatic conditions that proved it hard to prolong and utilize what was left by the Romans.

But the roman influenced Italian influence was again peering in British kitchens in the mid-20 $0^{\text {th }}$ century; with Mediterranean influence through cookbooks and magazines soon came the introduction of pizza. Italian immigrants opened pizzerias, which started to bloom in popularity. Ingredients unavailable were exported to the United Kingdom. With the eventual growth, supermarkets soon widened to offer the ingredients for Brits. Therefore, with Italian cuisine seeping in, through restaurants as well as through gastronomic literature, the English cuisine was introduced to starchy preparations such as pastas as well as wines, spirits and cheeses. ${ }^{11}$

\section{DESSERTS}

\subsection{PASTRY}

Early evidences of sweet treats can be found in writings as those in the plays of Aristophanes or presented in ancient tomb paintings, in the descriptions of pastry being utilized by the ancient Egyptians, Romans and Greeks. Utilizing the limited natural sweeteners available in that period, the ancient Egyptians, Greeks and Romans are believed to have used a type of filo pastry (a simple mixture consisting of flour and oil) to make sweet pastries, honey cakes, fruit tarts and dumplings having a stuffing of dates and nuts.

Moving forwards the Romans too created similar basic pastry dough consisting of flour, oil and water. This was only used as a protective layer to prevent the meat from drying out and also to protect the outside of the meat from burning. It was never meant to be consumed as food and was discarded after cooking. It's not until the late medieval period that fuller pastry recipes resembling the now-known shortcrust and puff versions were starting to be more widely incorporated.

The earliest known English language cookbook 'Forme of Cury' refers to the making of chastletes and coffins referring to early tart cases and pies. Most of these recipes dating early periods, especially through the period of the fifteenth century, include egg yolks and saffron. The latter was to add color to the dough. From here we deduce the introduction of hot water crust pastry. Hand-formed game pies were crafted skillfully gaining popularity as table centre-pieces, and were frequently associated with galas and banquets. The creation of puff pastry can be supposedly credited to Claude Gelée, famed French painter and apprentice cook, dating around 1645. But the earliest British version is recorded in 1692 was a hand-written manuscript by Hannah Bisaker. The recipe for 'puff paist' tells the reader to "lay some Butter in little Pecies" over the flour dough, before folding and rolling three times. (Fig.2)

\footnotetext{
${ }^{10}$ Madden, E., 2017. Cultural Influences On British Cuisine Through Colonization - Global Foodways. Retrieved from: https://adhc.lib.ua.edu/globalfoodways/culturalinfluences-on-british-cuisine-through-colonization/

${ }^{11}$ Welcome Italia. 2017. A Short History Of The Italian Cuisine Home And Abroad - Welcome Italia. Retrieved from: https://www.welcome-italia.co.uk/short-historyitalian-cuisine-home-abroad/ 


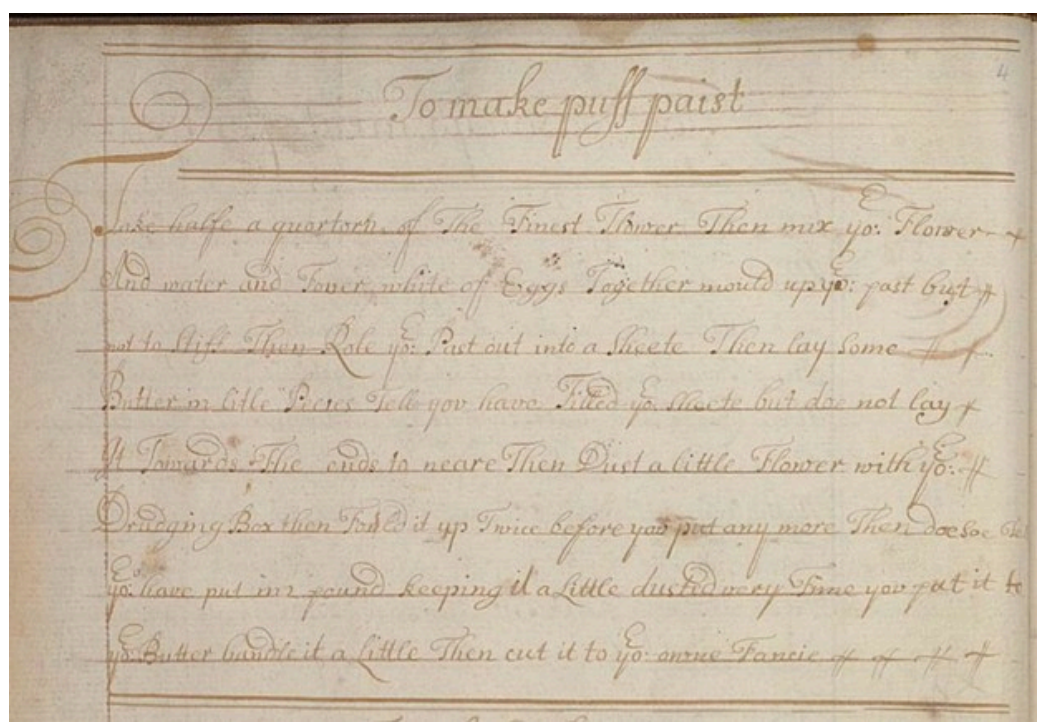

Figure 2: Handwritten Recipe Puff Pastry Recipe by Hannah Bisaker in 1692.

Source: https://www.historyextra.com/period/17th-century-great-british-bake-off-recipes/

Pastry-making became increasingly fashionable with British bakers in the seventeenth century. Bakers prided themselves on the intricate decorations and techniques used for their creations and were further inspired by the culinary developments taking place across the nation along with the European influence. After pastry-making had become a firmly established practice in British cuisine, the English variations of the dishes soon arose. Handily packaged in pastry for labourers in the Melton area around 1700s, Cornish pastry was seen by huntsmen visiting the area and word of these smaller versions of pies soon travelled afield. The Bedfordshire Clanger further improvised with a suet-pastry case which was enclosed with both main and dessert, packaging a savoury filling at one end and sweet at the other. But these failed in becoming popular and soon faded away. ${ }^{12}$

\subsection{PUDDINGS}

In modern Britain, pudding means anything sweet at the end of a meal. It appeared in satires as a symbol of the Empire, and illustrations as a symbol of family. A political pamphlet called 'A Learned Dissertation on Dumpling' released in 1726 read 'The Head of Man is like a Pudding'. But the term 'pudding' has only been connected to this last part of the meal since the twentieth century. In its early days, pudding started out as a savoury dish which was mostly meat-based, such as a haggis or a sausage, blood or entirely from rice, spelt or other grains stuffed into some kind of intestine or cloth bag. These puddings were always flavoured in one way or another, either using herbs or spices. Later, candied fruits, fortified wines and liqueurs were added and the puddings nearly all lost their meat contents. When the technique of steaming them in a basin or mould was developed, it became a more favoured method over traditionally boiling.

\subsection{CLOTTED CREAM}

Clotted cream is one of the most well-known dairy products known in the English cuisine for centuries. It is said to resemble a mix between butter and sweet thick cream. One of the earliest recipes found in gastronomic literature came from Thomas Dawson's 'The Good Huswifes Handmaide for the Kitchin', written in 1594. The clouted top develops when warming fresh milk for hours: recipes usually state to use the cow's morning milk and warm it till the evening, and that is when the crust develops on the top. It is that crust that makes this cream so distinctive. Through the ages very little about the method of preparing has changed. The pot of milk is placed on weak fire and the milk is either left alone until a crust develops, or a hole is made in the skin and cream is poured in and then the

${ }^{12}$ Gazzard, C., 2015. The History Of Pastry - Great British Chefs. Great British Chefs. Retrieved from: https://www.greatbritishchefs.com/features/history-of-pastry 
mixture is left to develop a crust. It has become more easier to make clotted cream with modern methods, needing to keep the cream warm for a very long time and for that safe ovens are used to make work easier.

\subsection{CAKES}

In Britain, Alexis Soyer was the chef at the Reform Club in the 1840s. He was well known throughout the land; hence any trend he would set was most likely to appear in the newspapers. Among his many endeavours, he had written a series of cookery books designed for every level of the market. For the growing urban middle classes there was The Modern Housewife (1850), written in the form of letters exchanged between two women; for the poor there was A Shilling Cookery for the People (1854); and for the wealthy there was The Gastronomic Regenerator (1846), in which he expresses his wish to set out 'a simplified and strikingly new system of cookery'. The book contains descriptions of some of the elaborate centrepieces he has prepared for banquets for the rich and famous: a Hure de Sanglier glacé en surprise (mock boar's head ice-cream cake), for example, or a Gâteau Britannique á l'Amiral (British admiral's cake), in which a sponge cake taking twenty eggs is baked in the form of a ship, with icings, pastes, jellies, wafers, marmalade and jam used to form guns and wood, waves and sails, the whole topped off with rigging made from spun sugar. It was likely this influence that widely introduced cakes to the cuisine. ${ }^{13}$

\subsection{ENGLISH TRIFLE}

The word "trifle" is derived from the old French word "trufle" which literally means something whimsical. A traditional English trifle comprises of an egg custard which is poured over a sponge cake and soaked in fruit and sherry. It is then topped with whipped cream as a finish. Similar to how most puddings evolved as a way of utilizing any leftovers, the English Trifle originated as a way to use any stale cake that may be left.

In the fourth edition of book The Art of Cookery, Made Plain and Easy, published in 1751, Hannah Glasse's recipe for a trifle changed the nature of trifles succeeding it. Hannah Glasse was known for having copied most of the recipes in her books from other cooks and authors without any disclosure on the subject. It is speculated that she might have likely, in those 30 years after Mary Eales published her trifle recipe, published the same but gave it the name 'trifle' when a dish like that would previously have been known as a 'Norfolk fool'. Glasse is speculated to have picked up the recipe from some source as it is not seen to be mentioned in her first editions. Hannah Glasse later went on to also publish a lesser known book called The Compleat Confectioner in 1760, in which she gives a recipe for 'A Grand Trifle'. And as with that reputation, Hannah Glasse might not have invented this dish as well. But it appears to be the earliest in print at present and also the first to include a layer of jelly as a base. ${ }^{14}$

\section{CONCLUSION}

From the study done above on the historical side of English cuisine, it can be agreed upon that almost every recipe or dish that is passed on to the next generation has a story to be told about the origins of that particular food preparation. Be it The Duchess of Bedford's idea of introducing a tea break between meals or the request of Earl of Sandwich for some meat between slices of bread to-go, it is fair to say that the constant pace of change the country was under, helped it to get accustomed to new practices. The nature of the cuisine lies in its history where the country has shown drastic changes in the diet of its people and the plentiful changes to its cuisine. The remarkable potency shown by the land in adapting, improvising and skillfully evolving its cuisine whilst also managing to stay true to its traditional ways shows potential in its adaptability and survival in the long run as a gastronomic pabulum.

\section{SOURCES OF FUNDING}

This research received no specific grant from any funding agency in the public, commercial, or not-for-profit sectors.

${ }^{13}$ Humble, N. (2010). Cake: A Global History. Reaktion Books.

${ }^{14}$ Ysewijn, R., 2016. Pride And Pudding. Murdoch Books.

International Journal of Research -GRANTHAALAYAH 


\section{CONFLICT OF INTEREST}

The author have declared that no competing interests exist.

\section{ACKNOWLEDGMENT}

None.

\section{REFERENCES}

[1] United Kingdom - Ancient Britain. (n.d.). Encyclopedia Britannica. Retrieved August 11, 2020, from https://www.britannica.com/place/United-Kingdom/Ancient-Britain

[2] Overton, M. (2010). Agricultural Revolution in England: The Transformation of the Agrarian Economy 15001850 (Cambridge Studies in Historical Geography) (First Edition). Cambridge University Press. p.59

[3] Hambrey, J. and Evans, S. (2016). Aquaculture in England, Wales and Northern Ireland: An Analysis of the Economic Contribution and Value of the Major Sub-Sectors and the Most Important Farmed Species. Hambrey Consulting, ISBN No: 978-1-911073-00-0, $24-25$.

[4] Pegge, S. (1780). The forme of cury: A roll of ancient English cookery. London: Printed by J. Nichols.

[5] Lemm, E. (n.d.). A Brief History of the Great British Sunday Roast. The Spruce Eats. Retrieved August 11, 2020, from https://www.thespruceeats.com/history-of-the-british-sunday-roast-4149600

[6] Castelow, E. (n.d.). The History of Fish and Chips - National Dish of Britain. Historic UK. Retrieved August 11, 2020, from https://www.historic-uk.com/CultureUK/Fish-Chips/

[7] Wilson, B. (2010). Sandwich: A Global History. Reaktion Books, 10 - 14.

[8] UK Essays. (n.d.). Traditional English Food and The History History Essay. UKEssays.Com. Retrieved August 11, 2020, from https://www.ukessays.com/essays/history/traditional-english-food-and-the-historyhistory-essay.php

[9] Bule, G. (n.d.). History of The Traditional English Breakfast. The English Breakfast Society. Retrieved August 11, 2020, from https://englishbreakfastsociety.com/full-english-breakfast.html

[10] Madden, E. (2017, December 15). Cultural Influences on British Cuisine through Colonization. Retrieved August 11, 2020, from https://adhc.lib.ua.edu/globalfoodways/cultural-influences-on-british-cuisinethrough-colonization/

[11] Italia, W. (2017, July 26). A Short History of the Italian Cuisine Home and Abroad. Welcome Italia. Retrieved August 11, 2020, from https://www.welcome-italia.co.uk/short-history-italian-cuisine-home-abroad/

[12] Chefs, G. B. (2020, July 16). The history of pastry. Great British Chefs. Retrieved August 11, 2020, from https://www.greatbritishchefs.com/features/history-of-pastry

[13] Humble, N. (2010). Cake: A Global History. Reaktion Books, 13 - 14.

[14] Ysewijn, R., 2016. Pride and Pudding. Murdoch Books. 